\title{
Pengenalan dan pengendalian hama jeruk siam di Desa Tanjung Kecamatan Koto Kampar Hulu Kabupaten Kampar
}

\author{
Hafiz Fauzana*, Rusli Rustam, Nelvia, Yetti Elfina, dan Muhammad Ali \\ Jurusan Agroteknologi, Fakultas Pertanian, Universitas Riau \\ * fauzana_hafiz@yahoo.co.id
}

\begin{abstract}
Abstrak. Tanaman jeruk merupakan salah satu komoditas hortikultura andalan di Kabupaten Kampar Propinsi Riau khususnya di Desa Tanjung Kecamatan Koto Kampar Hulu. Kendala utama budidaya jeruk adalah banyaknya serangan hama, pengalaman sebelumnya tanaman jeruk di Kabupaten Kampar harus dimusnahkan karena diserang CVPD dan Phythopthora spp. Pengabdian ini bertujuan untuk memberikan pengetahuan kepada petani di Desa Tanjung tentang jenis hama yang menyerang jeruk, gejala serangan, faktor-faktor yang mempengaruhi dan metoda pengendaliannya. Tujuan akhirnya adalah meningkatkan produksi jeruk sehingga pendapatan petani bertambah. Pengabdian dilaksanakan dengan metode penyuluhan dan demostrasi. Hasil dan ketercapaian program pengabdian berupa pengetahuan dan keterampilan petani meningkat tentang jenis hama dan teknik pengendalian yang ramah lingkungan pada tanaman jeruk. Metode pengabdian meliputi penyuluhan dan demonstrasi dalam kegiatan pengabdian sangat direspon baik oleh petani jeruk, materi pengenalan dan pengendalian hama jeruk belum pernah mereka terima, ditambah dalam budidaya tanaman jeruk kendala yang sering dihadapi petani adalah masalah hama sehingga petani peserta memperhatikan dengan baik, mengajukan banyak pertanyaan. Evaluasi ketercapaian dari hasil kuisioner dengan diadakan penyuluhan tentang hama jeruk ini petani jadi tahu jenis hama jeruk, gejala serangan, dan alternatif teknik pengendalian yang dilakukan mengingat selama ini petani jeruk hanya mengenal dan mengaplikasi teknik pengendalian menggunakan pestisida sintetik. Dengan demikian pengabdian ini memberi manfaat besar kepada petani jeruk dalam mengendalikan hama jeruknya.
\end{abstract}

Kata kunci: demostrasi; hama; jeruk; pengendalian; penyuluhan

\begin{abstract}
Citrus plants are one of the mainstay horticultural commodities in Kampar Regency, Riau Province, especially in Tanjung Village, Koto, Kampar Hulu District. The main obstacle to citrus cultivation is the large number of pest attacks. In the previous experience of citrus plants in Kampar Regency these plants had to be destroyed because theye were attacked by CVPD and Phythopthora spp. This service aims to provide knowledge to farmers in Tanjung Village about the types of pest that attack oranges, attack symptoms, influencing factors and control methods. The ultimate goal is to increase citrus production so that farmers' income increases. Dedication is given by counseling and demonstration methods. Results and achievements the service program resulted in improved farmers' knowledge and skills about the types of pest and environmentally friendly control techniques for citrus plants. The service method includes counseling and demonstration in service activities were very well responded by citrus farmers. Previously farmers had never received material on introduction and control of citrus pests, in addition they faced issues in citrus cultivation i.e. pest therefore e participants paid close attention and asked many questions. Evaluate the achievement of the results of the questionnaire by holding counseling about citrus pests, farmers became aware of types of citrus pest, attack symptoms, and alternative control techniques that are carried out since citrus farmers only had knowledge on and applied control techniques using synthetic pesticides. Thus this service provides great benefits to citrus farmers in controlling their citrus pests.
\end{abstract}

Keywords: citrus; control; demonstration; extension; pest

To cite this article: Fauzana, H., R. Rustam, Nelvia, Y. Elfina, \& M. Ali. 2019. Pengenalan dan pengendalian hama jeruk siam di Desa Tanjung Kecamatan Koto Kampar Hulu Kabupaten Kampar. Unri Conference Series: Community Engagement 1: 180-185. https://doi.org/10.31258/unricsce.1.180-185

(C) 2019 Authors

Peer-review under responsibility of the organizing committee of Seminar Nasional Pemberdayaan Masyarakat 2019 


\section{PENDAHULUAN}

Tanaman jeruk (Citrus nobilis Lour.; Rutaceae) adalah tanaman buah tahunan yang berasal dari Asia (Ridzal, 2008). Jeruk siam merupakan anggota jeruk keprok yang berasal dari Siam (Muangthai). Tanaman ini terus berkembang dan tersebar sampai ke Indonesia (Setiawan dan Trisnawati, 2003).

Jeruk siam yang terkenal adalah jeruk siam asal Kampar. Masyarakat menyebutnya sebagai jeruk siam Kampar karena dibudidayakan di Kabupaten Kampar. Jeruk siam asal Kampar memiliki rasa yang manis dan harum sehingga diminati oleh masyarakat Riau dan memiliki kulit buah yang tipis sehingga menjadi ciri khas yang membedakannya dari jenis jeruk manis yang lain (Widianti et al., 2012).

Tanaman jeruk khususnya di Desa Tanjung Kecamatan Koto Kampar Hulu banyak ditanam dengan luas lahan untuk perkebunan jeruk yaitu 150 ha yang merupakan milik beberapa warga Desa Tanjung. Jarak tempuh dari ibukota Kabupaten Kampar, Bangkinang adalah 60 km, jarak dari ibukota Provinsi Riau, Pekanbaru yaitu $120 \mathrm{~km}$. Desa Tanjung memiliki luas wilayah $30 \mathrm{~km}$ x $25 \mathrm{~km}$, yang dijadikan areal pemukiman $4 \mathrm{~km} \times 3 \mathrm{~km}$. Suhu udara di Desa Tanjung berkisar $21^{\circ} \mathrm{C}$ sampai $34^{\circ} \mathrm{C}$, dengan curah hujan $2000-3000 \mathrm{~mm}$ per tahun. Adapun batas wilayah Desa Tanjung yaitu sebelah utara berbatasan dengan Desa Pongkai dan Desa Tabing, sebelah timur berbatasan dengan Desa Gunung Bungsu dan Desa Muara Takus, sebelah selatan berbatasan dengan Desa Muara Takus dan Kabupaten 50 Kota (Sumatera Barat) dan sebelah barat berbatasan dengan Desa Tabing dan Nagari Muara Paiti Kabupaten 50 Kota (Sumatera Barat) (Anonim, 2016).

Desa Tanjung Kecamatan Koto Kampar Hulu, Kabupaten Kampar, Provinsi Riau. Kondisi umum wilayah Desa Tanjung adalah datar, bergelombang hingga berbukit dan produktifitas tanahnya termasuk tinggi sehingga banyak tanaman yang bisa tumbuh dengan subur. Desa Tanjung termasuk Desa yang tertua di Kecamatan Koto Kampar Hulu. Desa Tanjung sudah ada sebelum keberadaan Kerajaan Muara Takus. Desa Tanjung berdiri sebelum abad ke 7 sebelum Masehi, sejarah mengatakan bahwa pembangunan Candi Muara Takus melibatkan masyarakat Desa Tanjung pada waktu itu.

Kegiatan bercocok tanam cukup banyak dilakukan oleh warga Desa Tanjung karena pekerjaan masyarakat di Desa Tanjung adalah petani sebanyak 2.720 orang $(51,21 \%)$. Tanaman yang banyak ditanam adalah karet seluas 4.500 ha, kelapa sawit seluas 2.500 ha, padi sawah seluas 2.500 ha, Gambir seluas 1.500 ha, palawija seluas 200 ha dan kebun jeruk seluas 150 ha. Penduduk Desa Tanjung berjumlah sebanyak 5.713 jiwa dengan jumlah 1.478 Kepala Keluarga (Anonim, 2016).

Tanaman jeruk merupakan komoditi andalan yang kembali ingin dibudidayakan masyarakat Desa Tanjung. Mengingat pada tahun 1970-an Kampar menjadi sentra produksi jeruk, tetapi pada tahun 1980-an terjadi kemunduran akibat serangan penyakit CVPD (Citrus Vein Phloem Degeneration) dan Phythopthora yang menyebabkan seluruh kebun jeruk yang ada di wilayah tersebut mati sehingga produksinya terhenti (Kurniawan, 2011). Berdasarkan itu dari pengalaman terdahulu kendala utama dalam budidaya tanaman jeruk adalah serangan hama dan penyakit.

Perkebunan Jeruk yang ditanam oleh petani letaknya agak jauh dari pemukiman warga yaitu terletak di seberang sungai. Akses untuk menuju ke perkebunan jeruk, para petani jeruk menggunakan sampan/rakit sebagai sarana transportasi untuk sampai ke kebun. Saat ini, dari luasan 150 ha perkebunan jeruk yang ditanam oleh beberapa petani di Desa Tanjung, kebun yang sudah produktif lebih kurang seluas 0,4 ha sebanyak 120 batang tanaman jeruk. Kebun seluas 0,4 ha tersebut sudah lama ditanam oleh salah seorang petani jeruk sekaligus sebagai ketua kelompok tani tanaman jeruk di Desa tersebut. Disamping itu, tanaman yang ditanam oleh petani jeruk lainnya sudah mulai muncul bakal buahnya.

Tingkat pendidikan petani yang rendah yaitu kebanyakan tamatan SD dan SMP yang terlihat dari deskripsi lulusan penduduk (pendidikan penduduk Desa Tanjung adalah tamatan SD 2.417 orang (47,6\%), tamatan SMP sederajat 639 orang $(12,00 \%)$ tamatan SMA sederajat 437 (8,76\%). Pengetahuan petani tentang hama dan penyakit yang menyerang tanaman jeruk begitupun pengendaliannya masih sangat kurang (Komunikasi pribadi: Muhammad Ismet; penduduk Desa Tanjung). Oleh karena itu penyuluhan tentang jenis hama dan penyakit yang menyerang jeruk serta teknik pengendaliannnya adalah sangat penting untuk mencegah kegagalan penanaman jeruk pada tahun yang lalu yaitu 1980-an dan menyelamatkan produksi jeruk petani. 


\section{MASALAH}

Tanaman jeruk merupakan salah satu komoditi andalan hortikultura di Propinsi Riau, khususnya jenis jeruk siam (Citrus nobilis Lour.). Kabupaten Kampar merupakan sentral produksi jeruk siam di Propinsi Riau. Desa Tanjung Kabupaten Koto Kampar Hulu salah satu yang memproduksi jeruk siam.

Budidaya jeruk siam kendala utamanya adalah serangan hama dan penyakit. Jeruk di Kabupaten Kampar dulu diusahakan dalam jumlah yang besar dan kemudian dimusnahkan karena terserang CVPD dan Phythopthora sp, sekarang tanaman jeruk mulai diusahakan lagi di Kabupaten Kampar. Petani pembudidaya jeruk siam di desa Tanjung dan sekitarnya umumnya memiliki pengetahuan yang rendah (tamat SD dan SMP) dan pengetahuannya tentang hama dan penyakit tanaman jeruk serta cara pengendaliannya sangat kurang. Petani dalam menghadapi permasalahan hama dan penyakit jeruk dibantu oleh PPL, dan umumnya solusinya yang dianjurkan memakai pestisida sintetik. Petani jeruk di Desa Tanjung dan sekitarnya kurang mengetahui jenis-jenis hama dan penyakit yang menyerang jeruk, begitupun cara pengendaliannya.

Beberapa permasalahan yang dapat dirumuskan berkaitan dengan analisis situasi di atas yaitu sebagai berikut:

1. Petani jeruk di desa Tanjung belum begitu mengetahui jenis-jenis hama dan serangannya, vektor penyakit virus tanaman jeruk serta teknik pengendaliaannya.

2. Petani jeruk di Desa Tanjung belum begitu mengetahui gejala serangan penyakit dan faktor-faktor yang mempengaruhi perkembangan, serta pengendaliannya.

Dari identifikasi masalah tersebut dapat dirumuskan bahwa petani belum mengetahui banyak tentang hama dan penyakit tanaman jeruk. Pemahaman petani tentang hama dan penyakit serta cara pengendalian jeruk dirasa sangat perlu, oleh karena itu perlu dilakukan penyuluhan tentang pengenalan dan pengendalian hama dan penyakit (Fauzana et al., 2019), sehingga petani jeruk siam di Desa Tanjung dapat mengenal jenis hama dan penyakit yang menyerang dan dapat mengendalikan sendiri terutama dengan cara pengendalian secara alami dengan penggunaan pestisida sebagai alternatif terakhir sesuai konsep pengendalian hama terpadu.

\section{METODE}

Kegiatan penyuluhan dilaksanakan pada bulan Agustus tahun 2016. Metode yang digunakan untuk mencapai tujuan pengabdian adalah melalui beberapa pendekatan yaitu:

1. Penyuluhan berupa penyajian di dalam ruangan menggunakan alat bantu Laptop dan infocus dengan memperagakan jenis hama dan penyakit yang menyerang jeruk, dan gejala serangannya

2. Diskusi dan tanya jawab tentang hama dan penyakit tanaman jeruk serta teknik pengendaliannya

3. Demontrasi tentang cara praktis pengendalian hama jeruk menggunakan perangkap metil eugenol untuk mengendalikan hama lalat buah, dan perangkap Glumon untuk mengendalikan hama kutu, lalat buah dan hama lain jeruk

4. Praktek cara pembuatan pestisida nabati dari tanaman sirih hutan untuk mengendalikan hama dan penyakit pada tanaman jeruk.

Pelaksanaan kegiatan ini terdiri dari tiga tahap:

1. Tahap persiapan: Survei, persiapan materi, pemantauan lokasi, koordinasi, persiapan pelaksanaan, menuju lokasi, penyerahan surat yang diperlukan untuk melaksanakan kegiatan ini.

2. Tahap pelaksanaan: Pelaksanaan penyuluhan, pemaparan pengenalan hama dan penyakit jeruk, diskusi, tanya jawab, dan demonstrasi.

3. Tahap evaluasi: Akhir kegiatan disiapkan kuisioner untuk menentukan sejauhmana pemahaman petani dari pembinaan yang telah dilakukan, perubahan yang terjadi dari segi pemahaman keilmuaan dari kegiatan penyuluhan yang telah diberikan.

4. Penyusunan laporan: Pembuatan laporan, dan perbanyakan laporan.

\section{HASIL DAN KETERCAPAIAN}

Pengabdian masyarakat di Desa Tanjung Kecamatan Koto Kampar Hulu Kabupaten Kampar tentang pengendalian hama dan penyakit tanaman jeruk kegiatan meliputi penyuluhan dan demonstrasi (Gambar 1). Penyuluhan menyajikan tentang jenis-jenis hama dan penyakit yang menyerang tanaman jeruk, dan teknik pengendalian yang diterapkan terhadap masing-masing jenis hama dan penyakit tersebut. 


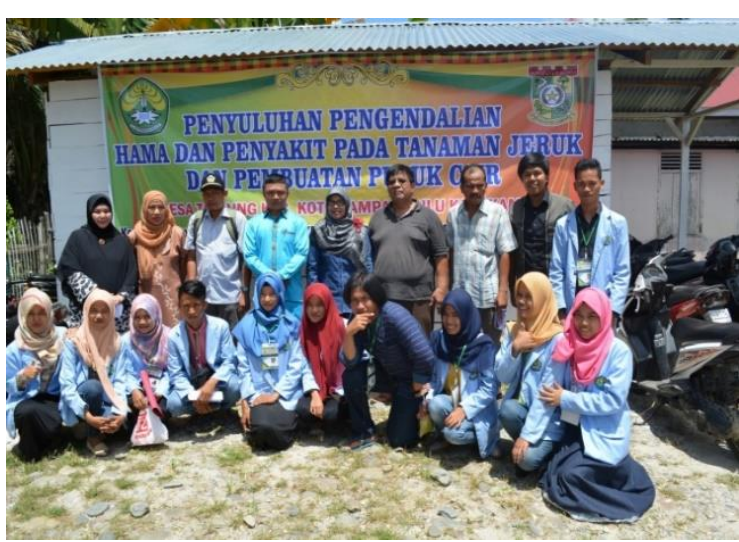

(a)

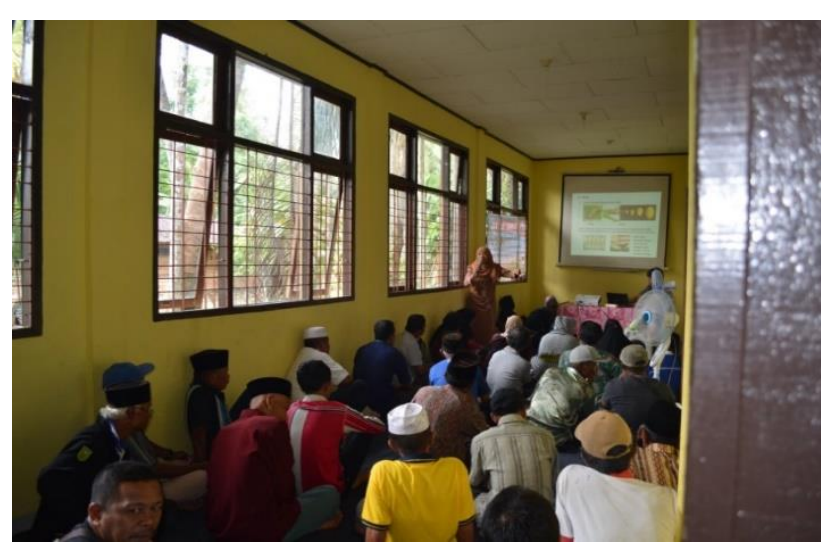

(b)

Gambar 1. (a) Partisipasi mahasiswa KKN UNRI dalam kegiatan penyuluhan sebagai pelaksana kegiatan, (b)

Pelaksanaan penyuluhan di ruang Kepala Desa Tanjung

Jenis-jenis hama yang menyerang tanaman jeruk umumnya adalah jenis kutu yaitu kutu loncat (Diaphorina citri), kutu sisik putih (Unaspis citri), kutu dompolan (Planococcus citri), kutu daun jeruk tropis (Toxoptera citricida), kutu daun hijau (Myzus persicae), dan kutu daun Aphis gossypii. Jenis kutu ini merupakan hama selain itu juga sebagai vektor virus yang memindahkan penyakit CVPD, penyakit virus Trizelia, dan penyakit virus lainnya ke tanaman jeruk yang sehat. Penyakit virus ini sangat dikawatirkan oleh petani jeruk di Kabupaten Kampar, karena dapat menyebabkan buah jeruk kecil-kecil dan mengalami kematian, penyebarannya tidak bisa dikontrol karena disebarkan oleh hama kutu. Hama yang lain menyerang tanaman jeruk adalah Thrips (Scitothrips citri) sebagai vektor penyakit virus, lalat buah (Bactrocera spp.) menyebabkan busuk buah jeruk, tungau karat (Phyllocoptura oleivera), penggerek buah (Citripestis sagittiferella), ulat pengerek bunga dan puru buah (Pray sp.), dan ulat peliang daun (Phyllocnistis citrella). Jenis Penyakit utama menyerang Jeruk adalah CVPD (citrus vein phloem degeneration), busuk pangkal batang (Phytophthora spp), Diplodia (Botryodiplodia theobromae Pat), embun tepung (Oidium tingitanium) dan penyakit antraknose (Balai Penelitian Tanaman Jeruk dan Buah Subtropika, 2016). Hama dan penyakit tersebut berpotensi besar menurunkan kualitas dan kuantitas buah jeruk.

Pemaparan materi jenis hama dan penyakit disajikan dengan laptop dan infocus yang dipaparkan adalah jenis-jenis hama, siklus hidup dalam bentuk gambar hamanya, dan teknik-teknik pengendaliannya. Satu jenis hama dijelaskan, langsung diberi kesempatan kepada petani untuk mengajukan pertanyaan. Selanjutnya, masuk ke jenis hama berikutnya dijelaskan lagi, kemudian tanya jawab, dan begitulah seterusnya. Untuk hama kutu yang merupakan vektor penyakit virus pengendaliannya terutama adalah menggunakan musuh alami, karena sangat banyak jenis musuh alami terutama predator yang dapat memangsa hama kutu. Oleh karena itu penyajian materi musuh alami sebagai pengendali kutu dikenalkan dalam bentuk gambar jenis-jenis predator, kemudian cara mengaplikasikannya.

Petani peserta penyuluhan sangat respon terhadap penyuluhan yang diberikan, karena materi yang disajikan tentang jenis hama dan penyakit, serta pengendaliannya pada tanaman jeruk sangat dibutuhkan oleh petani, karena kendala utama pada budidaya jeruk adalah masalah hama dan penyakit, sehingga benar-benar materi yang diharapkan petani. Mengingat pada tahun 1980-an terjadi kemunduran tanaman jeruk di Kabupaten Kampar akibat serangan penyakit CVPD (Citrus Vein Phloem Degeneration) dan Phythopthora yang menyebabkan seluruh kebun jeruk yang ada di wilayah tersebut mati sehingga produksinya terhenti (Kurniawan, 2011). Berdasarkan pengalaman terdahulu dimana selama 1 sampai 2 tahun tanaman jeruk dihentikan penananam untuk mengeliminasi siklus hidup penyakit CVPD, hal ini menyebabkan trauma tersendiri bagi petani, sehingga penyuluhan ini sangat direspon positif dan diterima secara antusias oleh petani jeruk di Desa Tanjung, petani banyak mengajukan pertanyaan-pertanyaan terutama tentang teknik pengendaliannya.

Kegiatan pengabdian berupa demonstrasi dilakukan setelah pemaparan menjelaskan materi hama dan pengendaliannya. Teknik-teknik pengendalian di demostrasikan, diperlihatkan teknik pengendalian hama jeruk yang telah dipaparkan pada materi penyuluhan. Teknik pengendalian hama lalat buah didemostrasikan cara pembuatan perangkap metil eugenol. Caranya botol plastik volume $600 \mathrm{ml}$ sepertiga bagian tutup botol dipotong dengan gunting, diletakan terbalik ke arah dalam botol, selanjutnya selingkarannya diberi selotip. Pada bagian tengah botol dilobangi untuk tempat masuknya kawat sampai tembus ke sebelahnya. Di tengah 
kawat diberi kapas, yang ditetesi dengan metil eugenol merek dagang Petrogenol sebanyak 0,25 ml. Bagian kiri dan kanan dilobangi tempat memasukan kawat untuk mengantung botol pada dahan tanaman jeruk, dasar botol diberi insektisida.

Demonstrasi pengendalian hama juga tentang pembuatan perangkap glumon untuk mengendalikan hama kutu, lalat buah, thrips, jenis hama lainnya. Caranya botol plastik putih bekas dioleskan dengan Glumon (mengandung metil eugenol untuk menarik lalat buah, memberi warna kuning sebagai penarik hama kutu yang suka warna kuning, dan mengandung lem untuk menjerap hama). Glumon dioleskan ke dinding botol menggunakan kuas. Perangkap ini digantung dengan tali rafia di dahan tanaman jeruk.

Pembuatan insektisida nabati dari daun sirih hutan untuk mengendalikan jenis-jenis hama dan penyakit tanaman jeruk yang banyak terdapat di Desa Tanjung juga didemostrasikan. Bahan-bahan yang digunakan adalah daun sirih hutan, air, sabun krim. Alat-alat yang digunakan adalah : handsprayer, blender, pengaduk, saringan, kain penyaring, erlenmeyer $1000 \mathrm{ml}$, dan gunting. Caranya daun sirih hutan dikering anginkan, dipotong kecil-kecil, diblender, dan disaring. Tepung daun sirih hutan ditimbang sebanyak $10 \mathrm{~g}$, dimasukan dalam erlenmeyer yang telah berisi $1000 \mathrm{ml}$ air, diaduk, didiamkan selama $1 \mathrm{jam}$, masukan $1 \mathrm{~g}$ sabun krim, diaduk kembali, disaring dengan kain saring. Ekstrak daun sirih hutan tersebut ditambahkan sabun krim, diaduk, dimasukan dalam hand sprayer dan siap untuk diaplikasi ke tanaman jeruk.

Demonstrasi pembuatan perangkap metil eugenol, perangkap glumon, dan pembuatan pestisida nabati daun sirih hutan sangat diminati dan direspon baik oleh peserta penyuluhan sehingga terjadi interaksi langsung yang intensif. Petani peserta memperhatikan dengan seksama, banyak bertanya tentang cara aplikasi yang belum dipahami. Materi yang didemostrasikan belum dikenal dan diterapkan petani pada praktek budidaya tanamannya. Petani hanya mengenal dan menggunakan pengendalian hama dalam praktek budidaya jeruk menggunakan pestisida sintetik. Teknik pengendalian yang dikenalkan seperti perangkap metil eugenol dianggap akan mengundang datangnya hama, dan Tim penyuluh bidang hama meluruskan persepsi yang salah tersebut. Petani sangat puas dengan materi pengendalian hama dan penyakit yang disajikan, begitupun teknik pengendalian yang didemostrasikan. Pada akhir penyuluhan dari hasil kuisioner yang diisi oleh petani dapat dijelaskan bahwa petani dapat memahami hama-hama jeruk dan pengendalian yang dipaparkan pada program penyuluhan.

\section{KESIMPULAN}

Penyuluhan tentang pengendalian hama dan penyakit tanaman jeruk di Desa Tanjung yang dilaksanakan dengan dua metoda. Pertama metode penyuluhan menggunakan media power point, dipaparkan dengan gambar hama, siklus hidup, kerusakan, beserta penjelasakan teknik pengendaliannya. Kedua metode demonstraksi berupa praktek teknik pengendalian yang terdiri dari pertama memperkenalkan pembuatan perangkap metil eugenol untuk mengendalikan lalat buah, kedua perangkap glumon untuk mengendalikan lalat buah, kutu, dan hama lainnya, dan ketiga cara pembuatan pestisida nabati daun sirih hutan.

Program pengabdian dalam bentuk penyuluhan dan demonstrasi sangat direspon baik oleh petani jeruk, penyuluhan dan demostrasi dengan materi pengenalan dan pengendalian hama jeruk belum pernah mereka terima, ditambah dalam budidaya tanaman jeruk kendala yang sering dihadapi petani adalah masalah hama dan penyakitnya sehingga petani peserta memperhatikan dengan baik, mengajukan banyak pertanyaanpertanyaan. Dengan demikian pengabdian ini akan memberi manfaat besar kepada petani jeruk dalam mengendalikan hama dan penyakit pada budidaya jeruknya.

\section{UCAPAN TERIMA KASIH}

Ucapan terima kasih kepada LPPM Universitas Riau atas diterimanya pengabdian ini untuk didanai dari sumber dana DIPA Universitas Riau Tahun anggaran 2016.

\section{DAFTAR PUSTAKA}

Anonim. 2016. Deskripsi Desa Tanjung Kecamatan Koto Kampar Hulu Kabupaten Kampar.

Balai Penelitian Tanaman Jeruk dan Buah Subtropika. 2016. Hama Penyakit Jeruk. http://balitjestro.litbang.pertanian.go.id/category/jeruk/ hama-jeruk/ Diakses pada 20 April 2016.

Fauzana, H., R. Rustam, Nelvia, Susilawati, Husnayetti, Irfandri, \& W. Wardati. 2019. Pengendalian hama padi secara terpadu di Desa Pulau Rambai Kabupaten Kampar. Riau Journal of Empowerment 2(1): 27-35. https://doi.org/10.31258/raje.2.1.21 
Kurniawan, M. 2011. Si Manis Dari Kuok. http://riaupos-forus.blogspot.com/2011/12/si-manis-dari-kuok.html Diakses pada 24 September 2012.

Ridzal, J. A. 2008. Analisis Faktor Determinan keikutsertaan petani Berkelompok, Pendapatan dan Pemasaran Jeruk Siam di Kabupaten Jember. J-SEP 2(1): 1-9.

Setiawan, A. I., dan Y. Trisnawati. 2003. Peluang Usaha dan Pembudidayaan Jeruk Siam. Jakarta: Penebar Swadaya.

Widianti, D. Iriani, dan Fitmawati. 2012. Pertumbuhan Bibit Poliembrioni Jeruk Siam (Citrus nobilis Lour.). http://jom.unri.ac.id/index.php/JOMFMIPA/article/download/2508/2442 